Co-op Farm. This compares with Roy's previous high count of 270 birds.

CINNAMON TEAL (Anas cyanoptera). A male was observed at a small dam approximately 1.5 miles north of the field station on May 29, 1967. Roy gives one record.

RED-T A L L D HAWK (Buteo jamaicensis). Recorded as a rare migrant in 1967 and 1968. Roy reported it an uncommon migrant and summer resident, most regular in the South Saskatchewan River Valley and adjacent coulees. Rising waters, which flooded many of the large trees in the river valley, have probably been responsible for the apparent decline in population.

RED-EYED VIREO (Vireo olivaceous). Not recorded in 1967-1968. Reported by Roy as an "uncommon transient . . . likely breeds in the South Saskatchewan River valley..."

WARBLING VIREO (Vireo gil$v u s)$. Not recorded in 1967-1968. Reported by Roy as a "fairly common summer resident." This and the above species are the most striking examples of status change effected by the flooding of the valley.

YELLOW - B R E A S TED CHAT (Icteria virens). We recorded one individual on July 28, 1967. Roy notes that a Saskatchewan Museum of Natural History party found them fairly common in the valley from Demaine westward in June of 1961.

B ULL OCK'S ORIOLE (Icterus bullockii). Three were sighted immediately south of the field station on May 27, 1967. Considered a "sporadic summer visitant" by Roy.

\section{Acknowledgements}

We wish to thank our fellow team members and Dr. William J. Maher, University of Saskatchewan, who supervised the programme. Financial support was by the National Research Council.

\section{LITERATURE CITED}

Houston, C. S., F. G. Bard, and R. W. Nero. 1958. Further information on certain unusual Saskatchewan bird records. Blue Jay, $16: 64-65$.

Roy, J. F. 1964. An introduction to the birds of the Elbow. Saskatchewan Natural History Society, Regina. Mimeo., 33 pp.

\title{
NESTING RECORDS OF THE YELLOW RAIL IN SASKATCHEWAN
}

\section{by C. Stuart Houston, Saskatoon}

The only unequivocal published record of a Yellow Rail nest in Saskatchewan is that of Edward Arnold, an oologist who found a nest with four eggs at the west end of Pasqua Lake west of Fort Qu'Appelle on May 31, 1895 (Arnold, 1896). In 1924, R. D. Symons found a nest recently trampled by cattle, believed to be of this species, in the Arm River Valley east of Davidson (Symons, 1956). The following records for the Yorkton area seem entirely plausible and therefore worth recording.

In the early 1930's, the late Charles H. Maddaford ran over two nests while mowing hay, on the NW quarter of section 16, township 23, range 3 , west of the second meridian - nine miles west and three miles south of Saltcoats, Saskatchewan. Both nests were in long grass on damp ground at the edge of water and each contained six or eight eggs. A small yellowish rail flushed off each nest, and he was certain they were not Soras, a familiar species whose nests he found nearly every year. The eggs were also different from those of the Sora; in telling me of this more than 20 years later, he thought they were lighter in color. He was certain of his identification of both the birds and their eggs because he had checked them carefully at the time in his bird book.

Mr. Maddaford showed me the book from which his identification had been made, but unfortunately much use had worn the letters from its cover and the title page had fallen out. There was no other identification anywhere in the book! He gave me the book, which I sent to a dealer in second- 
hand nature books but he could not identify it. This winter I resumed my quest and sent clues (such as the number of pages and plates, the author's residence near Fresh Pond in Cambridge, Massachusetts, and familiarity with eastern Canadian records) to Kathleen Anderson in Middleborough, Massachusetts. She obtained the answer fom Joseph A. Hagar, retired state ornithologist for Massachusetts. He identified the book as: A popular handbook of the birds of the United States and Canada by Thomas Nuttall, new revised and annotated edition by Montague Chamberlain, Little Brown \& Co., Boston, 1905.

Knowing Mr. Maddaford's reliability and his familiarity with the Sora, and his use of the Nuttall-Chamberlain book (pages 189 and 194 of part 2), I have little doubt that his identification was correct.

The late Frank Baines also told me that about 1900 he had found a single nest of the Yellow Rail near Crescent Marsh. This would be only about three miles northwest of the location of the two nests found years later by Maddaford. Baines was also very familiar with the Sora and its nests. Unfortunately he had no written record of this, and when he told me of it he was relying on his memory of 50 years before.

The Yellow Rail is a small secretive bird that skulks in marshy areas. It is rarely glimpsed and even more rarely can it be flushed to show its distinctive white wing patches. It is best recognized by its sound - like two stones being tapped together. Symons (1956) has given us the best account of the species in Saskatchewan, and a detailed account of Manley Callin's experiences in the Qu'Appelle Valley area will appear in his forthcoming publication Birds of the Qu'Appelle Valley. It has been recorded as far north as Prince Albert (Furniss, in Houston \& Street, 1959), Emma Lake (Mowat, 1947) and in a grass muskeg near the north end of Montreal Lake, June 30,1948 (Mowat, unpuiblished mss.).
The first Saskatchewan specimen was caught by E. E. Boynton by placing a hat over it in late August 1929, on the hay flats near Sagathun post office, 16 miles north of Maple Creek. The feathers were identified by P. A. Taverner (Godfrey, 1950). The next specimen was taken by Mrs. T. Willers of Viceroy, on May 31, 1930 , but no details are given (Potter, 1943). The next was collected on June 14, 1932 in a marsh at the north end of Last Mountain Lake; Albert C. Lloyd, with the Carnegie Museum party, finally captured it alive by falling on it from above (Todd, 1947)! The first specimen in the Saskatchewan Museum of Natural History was collected by R. D. Symons, three miles east of Battleford in 1934. Symons reported that at least three pairs were evidently nesting on the flats but that year and the following year all efforts, including dragging ropes through the marshes, failed to locate a nest (Bradshaw, 1935 and Symons, 1956). Ronald and Donald Hooper collected two specimens at the junction of the Bowman and Shand Creeks, north of Somme, on June 10, 1954 and sent one specimen to the S.M.N.H. (Hooper, 1959).

Additional specimens are reported by Belcher (1962) and Anweiler (1964).

\section{LITERATURE CITED}

Anweiler, G. 1964. Additional fall records of the Yellow Rail. Blue Jay, $22: 152$.

Arnold, E. 1896. My 1895 outing in Assiniboia. Oologist, $13: 19-21$

Belcher, M. 1962. First Yellow Rail record for Regina. Blue Jay, $20: 153$.

Bradshaw, F. 1935. Provincial Museum Annual Report for year ending April 30, 1935. p.2. Godfrey, W. E. 1950. Birds of the Cypress Hills and Flotten Lake regions, Sask. National Museum of Canada, Bulletin 120. Ottawa.

Hooper, R., and D. Hooper. 1959. Additions to the birds of Somme. Blue Jay, $17: 53$.

Houston, C. S., and M. G. Street. 1959. The birds of the Saskatchewan River, Carlton to Cumberland. Sask. Nat. Hist. Soc., Special Pub. No. 2.

Mowat, F. M. 1947. Notes on the birds of Em:na Lake, Sask. Canadian Field-Naturalist, $61: 109$.

Potter, L. B. 1943. Saskatchewan bird records made since the publication of Mitchell's Catalogue of Sask. Birds in 1924. Blue Jay, $1: 25$.

Symons, R. D. 1956. Random notes on the Yellow Rail. Blue Jay, 14 :8-9.

Todd, W. E. C. 1947. Notes on the birds of southern Saskatchewan. Annals Carnegie Museum, 30-396. 